\title{
A Química e as Novas Oportunidades num Mundo em Rápida Mudança Por Joaquim Luís Faria
}

Ensinar num contexto de incerteza e mudança tem obrigatoriamente de mudar a nossa perceção sobre a forma de como ensinamos. Seja a que nível for, desde o ensino primário à pós-graduação, é irrefletido recusar refletir sobre os meses que passaram e os anos que se avizinham. Será suficiente reduzir os eventos recentes a uma fatalidade pandémica e pensar em voltar à nossa rotina química, seja nos nossos laboratórios de investigação, nos cursos das nossas universidades, ou nas instalações das nossas empresas?

A mudança forçada e sob pressão para um ensino quase completamente remoto, online, ou mesmo híbrido, conduziu na maioria dos casos a adaptações na forma. Resultaram no que eufemisticamente classificamos como reformulação de práticas e métodos de ensino. Nalguns casos, não foram mais que novas formas de apresentar os mesmos Powerpoints que antigamente projetávamos em grandes anfiteatros, nem sempre reconvertidos para uma visualização em 12 polegadas ou menos, embora com o cuidado de deixar um canto vazio para a nossa janela Zoom ou para o tradutor de linguagem gestual obrigatório na Escola em Casa. Procurámos maneiras inovadoras de ensinar as reações químicas fundamentais presentes em todos os manuais, recorrendo a software tridimensional, filmes apelativos, e auxiliares digitais sofisticados como mesas gráficas, iPads, Tablets e respetivas canetas com ligação USB. Toda uma parafernália de meios para ampliar a interação, incentivar o diálogo e poder olhar os alunos de frente no écran, numa tentativa de tornar familiar esta relação híbrida de ensino/aprendizagem: o conjugar das (agora já antigas) salas de aula com os (novos) meios digitais, para no futuro aproveitar o melhor dos dois mundos.

Mas será que refletimos na mesma medida sobre quem são os nossos alunos de agora e quais os conceitos e ideias mais relevantes para as suas necessidades de aprendizagem nos tempos atuais? Os programas de ensino da química estão mesmo preparados para um mundo em constante evolução a uma velocidade quase alucinante? No ensino básico e secundário, surgiu em 2018 uma tentativa dinâmica de se estabelecer um referencial curricular sob a égide das Aprendizagens Essenciais (AE) - um conjunto de documentos de orientação curricular que tinham o objetivo de promover o desenvolvimento das áreas de competências inscritas no Perfil dos Alunos à Saída da Escolaridade Obrigatória (Despacho n. ${ }^{\circ}$ 9311/2016, de 21 de julho). Foi provavelmente a primeira vez, que de um modo estruturado, se abordaram as questões sobre o que os alunos deviam aprender em química, como deviam aprender, e o que podiam fazer com o que aprendiam. Em 2020/2021 estas AE chegaram finalmente ao ensino profissional! E em todo este processo a SPQ tem sido um parceiro, interveniente e ativo.

Agora, este debate requer continuidade nas universidades, seja para os cursos de ciências fundamentais, seja para as engenharias. Há que se debruçar efetivamente sobre qual a composição dos currículos de química que melhor preparariam os nossos estudantes, como cidadãos e como profissionais ativos. Qual a química necessária para um jovem graduado lidar com a complexidade atual, num mundo de evolução excecionalmente rápida, carregado de incertezas, receios e vulnerabilidades?

A SPQ, através do esforço de adaptação nestes últimos meses para manter a sua atividade como pilar de promoção e desenvolvimento da investigação, do ensino e da aplicação da Química em Portugal, fornece - através das suas Divisões, Grupos, Delegaç̧ões, dos Congressos, Eventos, Cursos de Formação, Olimpíadas, Reuniões e todas as restantes ações e atividades - uma plataforma privilegiada para este debate. É por isso que, ciente desse papel da Química neste novo mundo rapidamente em evolução, a SPQ organizará este ano o seu XXVII Encontro Nacional sob o tema A Química e as Oportunidades na Sociedade Global. É também por isso que contamos consigo: a participar ativamente e a trazer mais vozes para este debate.

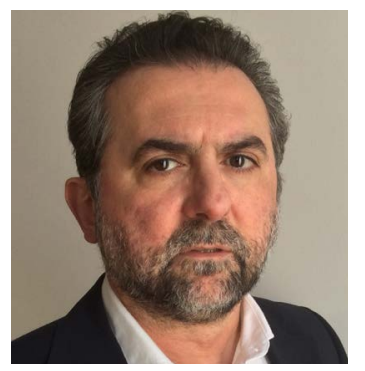

Joaquim Luís Faria

Vice-Presidente SPQ. Professor Associado com Agregação da FEUP. Investigador do LSRE-LCM. Colabora ativamente com a SPQ desde 1985. jlfaria@fe.up.pt

ORCID.org/0000-0002-6531-3978 